\title{
An Alternative Interpretation of Recent Political Science Journal Evaluations
}

\author{
James C. Garand, Louisiana State University
}

In their recent article in PS, Giles, Mizell, and Patterson (1989) provide a long-awaited update of an earlier article (Giles and Wright, 1975) on subjective evaluations by political scientists of a wide range of social science journals. In both articles, Giles and his collaborators sent questionnaires to a random sample of political scientists, asking them to rate each of the journals with which they were familiar on a scale from 0 to 10 with $0=$ poor, $2=$ fair, $4=$ adequate, $6=$ good, $8=$ very good, and $10=$ outstanding. Additional data were also collected on whether or not respondents were familiar with each journal. Based on the evaluation data, Giles et al. calculate the mean evaluation for each of the journals represented, as well as a ranking of the journals from most highly to least highly evaluated.

The mean ratings and the rankings of these journals that were calculated by Giles et al. are presented in columns (1) and (5) of Table 1, respectively. The rankings have a fair degree of face validity. For the most part, the major comprehensive journals in political science are found to be ranked highly, based on mean evaluations among those claiming to be familiar with the journal; the American Political Science Review, American Journal of Political Science, and Journal of Politics are all ranked in the top six journals, along with World Politics, American Sociological Review, and American Journal of Sociology. Further, several broad-based subfield journals are also ranked highly (e.g., International Organization, Comparative Politics, Political Theory).

However, an examination of these ratings yields some intriguing anomalies. What is surprising is that several journals with very narrow audiences and foci are also ranked very highly. For instance, the American Journal of International Law, Soviet Studies, Slavic Review, China Quarterly, Journal of Latin American Studies, and Journal of
Political Economy are ranked among the top 22 journals, even though in none of these instances is more than one-quarter of respondents familiar with the journal. These relatively high ratings are obviously due to the high evaluations given these journals by their relatively narrow readerships, and not necessarily because they are highly visible and broadly recognized for the quality of the scholarship contained within their pages.

What is surprising is that several journals with very narrow audiences and foci are also ranked very highly.

Many political scientists reading through the list of journals and their rank orderings might be surprised to find these narrow-focus journals ranked among the elite journals in our profession. While the reason for these high rankings is obvious-i.e., the small number of readers evaluate these journals highly-it might strike one as odd that the American Journal of International Law (with $18.6 \%$ of respondents familiar with it) is rated at a roughly equivalent level as the Journal of Politics (with $91.1 \%$ of respondents familiar with it). While the publication of an article in the former journal will be highly regarded by the $18.6 \%$ of political scientists who are familiar with it, an article published in the Journal of Politics is likely to have a broader level of visibility and, hence, have a greater potential impact in the profession. This does not mean that the impact of an article published in the former as opposed to the latter is not greater for scholars of international law; it only means that a broader range of political scientists is likely to be exposed to the equal- quality contribution found in the JOP.

The evaluation of a journal (and, presumably, the articles published within its pages) by its readers and others broadly familiar with it is only one component of journal quality. Another concept of interest to those concerned with the quality of professional media in political science is journal impact, which might be thought of as the combination of visibility and evaluation components. The impact of a journal in our profession hinges not only on the strength of evaluation by those reading the journal, but also by the number of political scientists who are likely to have regular access to its published findings. Two journals with similar evaluation levels might have very different impacts on the profession, depending upon the number of political scientists who regularly read articles in the journal and find the journal articles useful in their own professional work.

In this brief note I suggest an alternative interpretation of the Giles et al. data by combining the evaluation and familiarity indicators for each journal to form a measure of journal impact. In measuring journal impact, it is necessary to weight the evaluation indicator by the familiarity measure. This can be done simply by multiplying the mean evaluation by the proportion of respondents familiar with a given journal. Unfortunately, such a measure is much more highly correlated with familiarity $(r=0.9738)$ than evaluation $(r=$ 0.5438 ), so an alternative measure that weights the evaluation and familiarity indicators more evenly is needed. In order to accomplish this task, I take the mean evaluation from Giles et al., and add it to the mean evaluation weighted by the familiarity indicator. This yields the following measure of journal impact:

IMPACT $=$ EVALUATION + (EVALUATION * FAMILIARITY). 
This impact measure is almost equally correlated with familiarity $(r=0.8615)$ and evaluation $(r=$ 0.7952). The construction of this indicator is in keeping with the view that journals should score ratings points for having strong evaluations, but should also improve their standing as a function of how many political scientists are exposed to their highly regarded messages. Presumably, a journal with the highest possible impact would have a mean evaluation equal to 10.0 , and the proportion of political scientists familiar with the journal would be 1.000 . Of course, such a journal does not exist but, if it did, the impact score would be equal to 20 (i.e., 10.0 $+[10.0 * 1.000])$. A journal with a moderate evaluation of 6.0 and a moderate familiarity level of 0.400 would have an impact score of 8.4 (i.e., $6.0+[6.0 * 0.400]$ ). A journal with a very strong evaluation of 8.0 but with a very narrow readership of 0.100 would have an impact score of 8.8 (i.e., $8.0+\left[8.0^{*} .10\right]$ ), while a journal with a moderate reputation (6.0) but a broad readership $(0.600)$ would have an impact score of 9.60 (i.e., $6.0+[6.0 * 0.600])$. The point of all of this is that combined strong evaluations and high visibility yields a strong journal impact, while weaker evaluations and/or lower familiarity result in a lowering of the journal impact score.

In columns (3), (4), and (6) of Table 1, I present the computed journal impact scores, the standardized scores, and the impact rankings, respectively, for the 78 journals in the Giles et al. recent study. As one can readily see, the major, broadbased journals in our profession take on the highest impact rankings, with the American Political Science Review (ranked 3rd by Giles et al.), Journal of Politics (6th), and American Journal of Political Science (5th) having the highest impact. World Politics, American Sociological Review, and American Journal of Sociology move from the 1 st, 2nd, and 4th positions to the 4th, 5th, and 6th positions, respectively. This is probably an accurate assessment of the relative general significance of these journals to the political science profession. Although those political scientists familiar with
TABLE 1.

Revised and Original Political Scientists' Ratings of Selected Journals

\begin{tabular}{|c|c|c|c|c|c|c|}
\hline Journal & $\begin{array}{c}\text { (1) } \\
\text { Mean } \\
\text { Rating }\end{array}$ & $\begin{array}{l}\text { (2) } \\
\text { Proportion } \\
\text { Familiar }\end{array}$ & $\begin{array}{l}\text { (3) } \\
\text { Journal } \\
\text { Impact }^{\text {a }}\end{array}$ & $\begin{array}{l}\text { (4) } \\
\text { Standard } \\
\text { Score }\end{array}$ & $\begin{array}{c}\text { (5) } \\
\text { Evaluation } \\
\text { Ranking }\end{array}$ & $\begin{array}{c}\text { (6) } \\
\text { Impact } \\
\text { Ranking }\end{array}$ \\
\hline \multicolumn{7}{|l|}{ American Political Science } \\
\hline Review & 7.6 & .986 & 15.09 & 3.17 & 3 & 1 \\
\hline Journal of Politics & 7.4 & .911 & 14.14 & 2.73 & 6 & 2 \\
\hline \multicolumn{7}{|l|}{ American Journal of } \\
\hline Political Science & 7.5 & .832 & 13.74 & 2.54 & 5 & 3 \\
\hline World Politics & 7.9 & .595 & 12.60 & 2.02 & 1 & 4 \\
\hline \multicolumn{7}{|l|}{ American Sociological } \\
\hline Review & 7.6 & .549 & 11.77 & 1.63 & 2 & 5 \\
\hline \multicolumn{7}{|l|}{ American Journal of } \\
\hline Sociology & 7.5 & .502 & 11.26 & 1.40 & 4 & 6 \\
\hline Foreign Affairs & 6.4 & .758 & 11.25 & 1.39 & 21 & 7 \\
\hline Comparative Politics & 7.0 & .553 & 10.87 & 1.21 & 10 & 8 \\
\hline \multicolumn{7}{|l|}{ British Journal of Political } \\
\hline Science & 6.8 & .581 & 10.75 & 1.16 & 13 & 9 \\
\hline Western Political Quarterly & 6.0 & .785 & 10.71 & 1.14 & 35 & 10 \\
\hline \multicolumn{7}{|l|}{ Public Administration } \\
\hline Review & 6.6 & .577 & 10.41 & 1.00 & 17 & 11 \\
\hline Public Opinion Quarterly & 6.4 & .605 & 10.27 & .94 & 23 & 12 \\
\hline Daedalus & 6.3 & .626 & 10.24 & .92 & 25 & 13 \\
\hline Polity & 6.0 & .692 & 10.15 & .88 & 37 & 14 \\
\hline \multicolumn{7}{|l|}{ PS: Political Science \& } \\
\hline Politics & 5.4 & .869 & 10.09 & .85 & 64 & 15 \\
\hline \multicolumn{7}{|l|}{ Journal of Conflict } \\
\hline Resolution & 6.4 & .575 & 10.08 & .85 & 20 & 16 \\
\hline Political Science Quarterly & 6.0 & .662 & 9.97 & .80 & 38 & 17 \\
\hline \multicolumn{7}{|l|}{ Administrative Studies } \\
\hline Quarterly & 6.9 & .428 & 9.85 & .74 & 12 & 18 \\
\hline International Organization & 7.1 & .377 & 9.78 & .71 & 9 & 19 \\
\hline \multicolumn{7}{|l|}{ Annals of the American } \\
\hline $\begin{array}{l}\text { Academy of Political } \\
\text { and Social Science }\end{array}$ & 5.4 & .808 & 9.76 & .70 & 62 & 20 \\
\hline Social Science Quarterly & 6.1 & .567 & 9.56 & .60 & 32 & 21 \\
\hline \multicolumn{7}{|l|}{ Comparative Political } \\
\hline Studies & 6.5 & .460 & 9.49 & .57 & 18 & 22 \\
\hline \multicolumn{6}{|l|}{ International Studies } & \\
\hline Quarterly & 6.5 & .419 & 9.22 & .45 & 19 & 23 \\
\hline \multicolumn{7}{|l|}{ American Politics } \\
\hline Quarterly & 5.8 & .589 & 9.22 & .45 & 45 & 24 \\
\hline Legislative Studies & & & & & & \\
\hline Quarterly & 6.1 & .488 & 9.08 & .38 & 31 & 25 \\
\hline American Journal of & & & & & & \\
\hline International Law & 7.3 & .186 & 8.66 & .19 & 7 & 26 \\
\hline Public Interest & 5.8 & .484 & 8.61 & .16 & 50 & 27 \\
\hline Publius & 5.8 & .467 & 8.51 & .12 & 47 & 28 \\
\hline Political Theory & 6.6 & .280 & 8.45 & .09 & 16 & 29 \\
\hline Journal of Political & & & & & & \\
\hline Economy & 6.8 & .238 & 8.42 & .07 & 14 & 30 \\
\hline Social Forces & 6.2 & .326 & 8.22 & -.02 & 28 & 31 \\
\hline Canadian Journal of & & & & & & \\
\hline Political Studies & 6.1 & .344 & 8.20 & -.03 & 30 & 32 \\
\hline Law and Society Review & 6.2 & .313 & 8.14 & -.05 & 26 & 33 \\
\hline Public Choice & 6.0 & .330 & 7.98 & -.13 & 36 & 34 \\
\hline Review of Politics & 5.7 & .397 & 7.96 & -.14 & 53 & 35 \\
\hline Urban Affairs Quarterly & 6.1 & .298 & 7.92 & -.16 & 34 & 36 \\
\hline Politics and Society & 6.0 & .312 & 7.87 & -.18 & 39 & 37 \\
\hline Soviet Studies & 7.2 & .093 & 7.87 & -.18 & 8 & 38 \\
\hline Policy Sciences & 5.9 & .333 & 7.86 & -.18 & 40 & 39 \\
\hline International Affairs & 6.2 & .260 & 7.81 & -.21 & 27 & 40 \\
\hline Political Studies & 6.2 & .247 & 7.73 & -.24 & 29 & 41 \\
\hline Government and & & & & & & \\
\hline Opposition & 5.8 & .330 & 7.71 & -.25 & 48 & 42 \\
\hline China Quarterly & 6.6 & .159 & 7.65 & -.28 & 15 & 43 \\
\hline European Journal of & & & & & & \\
\hline Political Research & 6.3 & .210 & 7.62 & -.29 & 24 & 44 \\
\hline Political Behavior & 5.7 & .326 & 7.56 & -.32 & 52 & 45 \\
\hline Policy Studies Journal & 5.0 & .507 & 7.54 & -.33 & 70 & 46 \\
\hline
\end{tabular}


TABLE 1. (continued)

\begin{tabular}{|c|c|c|c|c|c|c|}
\hline Journal & $\begin{array}{l}\text { (1) } \\
\text { Mean } \\
\text { Rating }\end{array}$ & $\begin{array}{l}\text { (2) } \\
\text { Proportion } \\
\text { Familiar }\end{array}$ & $\begin{array}{c}\text { (3) } \\
\text { Journal }^{\mathrm{a}} \\
\text { Impact }^{\text {and }}\end{array}$ & $\begin{array}{l}\text { (4) } \\
\text { Standard } \\
\text { Score }\end{array}$ & $\begin{array}{l}\text { (5) } \\
\text { Evaluation } \\
\text { Ranking }\end{array}$ & $\begin{array}{c}\text { (6) } \\
\text { Impact } \\
\text { Ranking }\end{array}$ \\
\hline $\begin{array}{l}\text { Slavic Review } \\
\text { Presidential Studies }\end{array}$ & 7.0 & .074 & 7.52 & -.34 & 11 & 47 \\
\hline Quarterly & 4.6 & .633 & 7.51 & -.35 & 72 & 48 \\
\hline Administration and Society & 5.8 & .293 & 7.50 & -.35 & 44 & 49 \\
\hline $\begin{array}{l}\text { Journal of Peace Research } \\
\text { American Behavioral }\end{array}$ & 5.7 & .312 & 7.48 & -.36 & 54 & 50 \\
\hline Scientist & 5.3 & .395 & 7.39 & -.40 & 66 & 51 \\
\hline Public Policy & 6.1 & .201 & 7.33 & -.43 & 33 & 52 \\
\hline Dissent & 5.5 & .332 & 7.33 & -.43 & 58 & 53 \\
\hline $\begin{array}{l}\text { Orbis } \\
\text { Journal of Latin American }\end{array}$ & 5.2 & .405 & 7.31 &.- .44 & 68 & 54 \\
\hline $\begin{array}{l}\text { Studies } \\
\text { Journal of Developing }\end{array}$ & 6.4 & .131 & 7.24 & -.47 & 22 & 55 \\
\hline Areas & 5.8 & .234 & 7.16 & -.51 & 51 & 56 \\
\hline $\begin{array}{l}\text { Law and Policy } \\
\text { American Review of }\end{array}$ & 5.9 & .177 & 6.94 & -.61 & 42 & 57 \\
\hline Public Administration & 5.5 & .262 & 6.94 & -.61 & 60 & 58 \\
\hline $\begin{array}{l}\text { Judicature } \\
\text { Public Administration }\end{array}$ & 5.8 & .196 & 6.94 & -.61 & 46 & 59 \\
\hline $\begin{array}{l}\text { Quarterly } \\
\text { Journal of International }\end{array}$ & 5.3 & .294 & 6.86 & -.65 & 67 & 60 \\
\hline Affairs & 5.9 & .158 & 6.83 & -.66 & 43 & 61 \\
\hline Political Quarterly & 5.4 & .238 & 6.69 & -.73 & 63 & 62 \\
\hline Asian Survey & 5.5 & .214 & 6.67 & -.73 & 59 & 63 \\
\hline Behavioral Science & 5.4 & .223 & 6.60 & -.77 & 61 & 64 \\
\hline $\begin{array}{l}\text { Journal of Inter-American } \\
\text { Studies and World }\end{array}$ & & & & & & \\
\hline Affairs & 5.9 & .107 & 6.53 & -.80 & 41 & 65 \\
\hline $\begin{array}{l}\text { Journal of Asian Studies } \\
\text { International Social }\end{array}$ & 5.8 & .121 & 6.50 & -.81 & 49 & 66 \\
\hline Science Journal & 5.3 & .205 & 6.39 & -.87 & 65 & 67 \\
\hline International Interactions & 5.6 & .130 & 6.33 & -.90 & 57 & 68 \\
\hline Social Science Journal & 5.2 & .200 & 6.24 & -.94 & 69 & 69 \\
\hline Middle Eastern Studies & 5.6 & .112 & 6.23 & -.94 & 56 & 70 \\
\hline Far Eastern Survey & 5.7 & .088 & 6.20 & -.95 & 55 & 71 \\
\hline Political Science & 4.9 & .163 & 5.70 & -1.19 & 71 & 72 \\
\hline National Civic Review & 4.5 & .200 & 5.40 & -1.33 & 73 & 73 \\
\hline Women and Politics & 4.4 & .131 & 4.98 & -1.52 & 74 & 74 \\
\hline Journal of Black Studies & 4.3 & .126 & 4.84 & -1.58 & 75 & 75 \\
\hline $\begin{array}{l}\text { Simulation and Games } \\
\text { Experimental Study of }\end{array}$ & 4.1 & .079 & 4.42 & -1.78 & 76 & 76 \\
\hline $\begin{array}{l}\text { Politics } \\
\text { Southeastern Political }\end{array}$ & 4.0 & .098 & 4.39 & -1.79 & 77 & 77 \\
\hline Review & 3.5 & .140 & 3.99 & -1.98 & 78 & 78 \\
\hline
\end{tabular}

the two sociology journals give them strong evaluations, it is most certainly the case that articles published in those journals are less likely to have the broad exposure to the political science community that one would expect to observe from a publication in one of the three broad-based political science journals. Even though the two sociology journals have slightly higher means evaluations than some of the major political science journals, the greater visibility of the latter means that they most certainly have a greater impact on the political science profession.

Once one moves below the very highest ranked journals, there are some significant differences in the evaluation-based rankings and the impact-based rankings. Several journals (particularly several of the broad-based regional and subfield journals) move up to more prominant positions in the rankings. Comprehensive or regional journals such as the Western Political Quarterly (35th to 10th), Polity (37th to 14th), PS: Political Science \& Politics (64th to 15th), Political Science Quarterly (38th to 17th), Social Science Quarterly (32nd to 21st), Annals of the American Academy of Political and Social Science (62nd to 20th), and American Politics Quarterly (45th to 24 th) all move up in the rankings, as do prominent subfield journals such as Foreign Affairs (21st to 7th), Public Administration Review (17th to 11th), Public Opinion Quarterly (23rd to 12th), and Publius (47th to 28th).

Of course, many of the journals with strong evaluations but lower levels of visibility (including some with relatively narrow foci) move down in the impact rankings: International Organization (9th to 19th), American Journal of International Law (7th to 26th), Soviet Studies (8th to 38th), China Quarterly (15th to 43rd), Slavic Review (11th to 47th), Public Policy (33rd to 52nd), Journal of Latin American Studies (22nd to 55th), Journal of Inter-American Studies and World Affairs (41st to 65th), and Journal of Asian Studies (49th to 66th). For the most part, these journals are well regarded by those familiar with their contents, but the low levels of visibility would indicate that the profession-wide impacts of these journals are lower than one might suggest, given the evaluations of those familiar with the journals.

Finally, many of the journals retain their relative standings in both the evaluation-based and impactbased rankings. (This is not too surprising, since Giles et al. report the correlation between familiarity and evaluation to be $r=0.39$.) Journals such as Comparative Politics, British Journal of Political Science, Journal of Conflict Resolution, Comparative Political Studies, International Studies Quarterly, and Legislative Studies Quarterly are ranked similarly highly on both rankings. It is perhaps noteworthy that the six lowest-ranked journals are identical on both rankings.

What is one to make of all of this? It is not my intention to suggest that the new rankings reported here are in any way superior to those reported by Giles et al. Instead, I use the data provided by Giles et al. to suggest a different interpretation that might be of use in assessing the professional media of political science. The rankings reported by Giles et al. can best be interpreted as representing the relative evaluations of journals by those who are most familiar with the 
content of those journals. Some journals have very little visibility, but those who communicate their research findings within the pages of those journals may be perfectly content with what they find therein. The rankings that I report here tap into a different evaluative dimension for political science journals. Journal impact, I would suggest, is a function of both the evaluations of a journal by those familiar with it, but also of the visibility of the journal to a wide range of political scientists. Having a lower general impact does not mean that a journal is not highly regarded by political scientists writing and reading in specific subfields to which the journal is directed, but only that the combination of evaluation and profession-wide visibility is lower than for other, more highly ranked journals.

The use of these two sets of rankings will depend upon the values that one brings to the evaluation process. Some political scientists, administrators, or departments will be interested in making assessments based on how journals are perceived by the (sometimes narrow) audiences with exposure to the journal. For instance, in hiring, promotion, and tenure decisions some faculty and administrators may be concerned with whether a candidate is publishing in journals that are highly regarded by the experts in a specific field, regardless of profession-wide visibility; in such a case, a publication in China Quarterly by a Chinese

The impact of a journal in our profession hinges not only on the strength of evaluation by those reading the journal, but also by the number of political scientists who are likely to have regular access to its published findings.

politics expert or in the Journal of Latin American Studies by a Latin Americanist may carry great weight. On the other hand, some in our profession will want to make assessments based on both the evaluation and profession-wide visibility of a journal. In these cases, a publication in the American Political Science
Review, World Politics, Comparative Politics, Journal of Conflict Resolution, or Daedalus may be perceived as reaching a wider audience and, therefore, contributing more broadly to the visibility and/or national reputation of the individual or department in question. Of course, the selection of evaluative criteria for making these types of decisions is a value judgment. But having two sets of journal rankings may assist those who have made their value judgments in making relevant evaluative decisions.

\section{References}

Giles, Micheal, Francie Mizell, and David Patterson. 1989. "Political Scientists' Journal Evaluations Revisited." PS: Political Science and Politics 22: 613-17. Giles, Micheal and Gerald Wright. 1975. "Political Scientists' Evaluations of SixtyThree Journals." PS: Political Science and Politics 8: 254-57.

\section{About the Author \\ James C. Garand is associate professor of political science at Louisiana State University. He has published in the American Political Science Review, Journal of Politics, Western Political Quarterly, Legislative Studies Quar- terly, and the American Politics Quarterly.}

\title{
Interviewing Political Elites
}

\author{
Robert L. Peabody, Johns Hopkins University \\ Susan Webb Hammond, American University \\ Jean Torcom, California State University, Sacramento \\ Lynne P. Brown, New York University \\ Carolyn Thompson, Johns Hopkins University \\ Robin Kolodny, Johns Hopkins University
}

Interviewing political elites-Presidents and Cabinet members;

Senators and Representatives;

Supreme Court Justices; White House, executive branch and congressional staff; political party and congressional campaign committee officials; lobbyists and media personnel-is both an art and a craft. All of these people, even those who have stepped down from their official duties, are busy and value their time. Hence, those who seek interviews with them must prepare carefully and use interviewing time wisely. The same admonition applies to those who choose to interview the state and local counterparts of these national elites. Since so many political scientists conduct interviews with political elites-as preparation for a dissertation, an article, or a bookthe authors thought it would be helpful to share with our colleagues the techniques and strategies that have worked well for us in a wide variety of field settings and interview situations.

Our argument is simply this: Techniques of interviewing political elites can be taught and disseminated; the art of interviewing respondents and informants can best be learned from experience. This article provides information about (1) when interviews are an appropriate research strategy; (2) ways of drafting a focused, semi-structured interview schedule; (3) means of obtaining 